\title{
EXAMINATION OF THE IMPACT OF HEALTH STATUS ON ECONOMIC PERFORMANCE IN HUNGARY
}

\section{Izabella Mária Bakos*, Csaba Bálint}

Szent István University, Gödöllő, Hungary

For a long time it has been a well-known and proven fact that economic growth of a country contributes to improvement of the health status of population. There is at the same time another type of opposite relationship starting from health status and pointing to the performance of economy. In our study, besides giving a general presentation of the health situation in Hungary, we examined the direction and strength of the relations between health and economic indicators and the inequalities that can be identified between the different regions with help of statistical methods. Another objective of the study was to examine the factors influencing mortality, and to develop a multiple linear regression equation to estimate the degree of mortality at a confidence interval of $95 \%$. The results could provide a good basis to determine the intervention points necessary to alleviate and improve the economic burden of bad health status and diseases.

Keywords: health status; healthcare; economic performance; Hungary

\section{Introduction}

Since 1986, the goal of the regional policy of the European Union has been to strengthen economic and social cohesion. The problem of territorial inequalities has nowadays become a central issue with the accession of new countries to the European Union (EU, 2013). Economic growth clearly implies the legitimate development of territorial differences, which can lead to serious regional inequalities without constant analysis and monitoring (Káposzta, 2014).

Besides the economic inequalities between developed and developing countries and inside the countries, we assist to the intensification of studies concerning health inequalities and the possible health policy answers prepared by a lot of countries and international organisations (WHO, World Bank, EU), (Orosz, 2001). The social and territorial distribution and characteristics of healthcare systems and health statuses can best be grasped with the notion of inequality (Smith, 1982; Jones and Moon, 1987, In Uzzoli, 2009).

Numerous research studies have given proof of the consequences that a worse general health level may have on economic development (Bognár, 2011), but less research has been carried out on the opposite relationship between health status and economic performance (Kollányi and Imecs, 2007). Before analysing the relations between health status and the situation of economy, let us refer to the meaning of these concepts in the specialized literature. "Health is a state of complete physical, mental and social wellbeing and not merely the absence of disease or infirmity" (WH0, 2001). This interpretation has recently been completed by the consideration that to be healthy is the capacity of an individual to live a socially and economically active life (Ágoston et al., 2007). In economic sense, health is a special good with characteristics that may influence economic efficiency (Bognár, 2011), meaning that health is a "good that cannot be replaced by anything else", the absence of health destroys the capacity of an individual to perform gainful activities, its demand is not determined by solvency, and time, quality, and duration of its restoration cannot be planned in advance" (Gidai, 1998). The concept of the economy appears also with several interpretations in specialized literature. According to Porter (2003) the standard of living of a nation is determined by economic productivity which measures the quantity of goods and services produced by a country with help of human, financial and natural resources. Productivity makes it possible for a nation to support high wages, strong currency, capital recovery, and consequently high living standards. The Competitiveness Council of the European Union also follows a productivity approach, when it writes that competitiveness stems from the increase of productivity embodied in the success of European enterprises at international markets and higher living standards perceivable by everybody. At the same time, it links the increase of the living standards to the increase of real incomes. According to the definition given by Sági (2005, In Varga, 2014) competitiveness refers to economic and structural policies that contribute to the productivity of a given economy. In our study we will use the concept of economic productivity to measure the situation of the economy.

Like other developed countries, Hungary is also characterized by important territorial inequalities in terms of the situation of its economy, health status and the health care delivery system (ESKI, 2013). Furthermore, the European Union has also recognized the need to invest in health and considers the good health status of the population as a precondition for intelligent, sustainable and inclusive development (EU, 2009). Health is the basis of the well-being of the society and only those countries can be successful where health is a vital issue for the society, for example as Finland, Great Britain and Ireland. Consequently, health care must be seen as an investment injected to improve the quality of life, productivity, GDP and competitiveness (Baráth, 2010). Agreeing with the two authors Kollányi and Imecs (2007), we are also of the opinion that health can be transformed into direct economic advantages both at individual level and at the level of the enterprises and the national economy, and this consideration has been motivational in order to develop this subject in our selected research.

Citizens of the European Union live healthier and longer than in previous generations, but huge differences between and within member states in health status, health expenditures, activity, and the spread of new and expensive technologies have been increasingly challenging (EC, 2009). The overall health status of a population affects individual, corporate and national economic performance through four intermediary main channels, namely: labour market participation and productivity, education, accumulation/ saving of physical capital and demographic transition. A healthy person works more efficiently, spends less time in sick leave, and is able to work longer in life than those who have a worse health status. The general health status and 
rising life expectancy encourage individuals to spend more time and resources on their own training.

In parallel with the rapid decline of births and deaths, the proportion of active people in society is growing, which gives the economy a boost. As a result of the decline in infant mortality, it will be worthwhile to educate children in health, which can lead to rapid and spectacular accumulation of human capital (Kollányi and Imecs, 2007). In addition to investing in active years, it is also important to invest in old-age care in the form of savings, which contributes to an increase in the volume of investments and is expected to generate economic growth (Malmberg and Andersson, 2006). In short, there is a number of channels that are points of attachment between health status and economic performance, both at individual and macro levels.

It is important to mention the economic burden of the poor health status and illnesses, which are serious problems both for individuals and the national economies. In the European Union and Hungary, there is a continuous increase in healthcare expenditure. Aging society and poor health result in declining income-generating capacity, which decreases healthcare contributions that deteriorate the quality of care and create a vicious circle putting people in need of care and health systems in a difficult situation. Illnesses have direct, indirect and intangible costs. The direct costs of the diseases are treatments, medicines and other remedies directly related to the disease. In Hungary, these costs are funded fundamentally by the National Institute of Health Insurance Fund Management (NEAK, former OEP). The indirect burden is mainly due to items that mean a loss to the economy or society because of the loss of work caused by the illness, and these are supplemented with the management and other costs of the NEAK that manages direct costs. It is important to note that lasting loss of production is possible only in professions where there is a shortage or in very special cases (Ács et al., 2011). Contrary to African developing countries, non-contagious diseases represent the biggest burden in Europe. Among them, cardiovascular diseases and psychological illnesses are the main problems. The four most common risk factors include diabetes mellitus, obesity, smoking and alcohol consumption (EC, 2005).

Based on what has been discussed so far, it can be seen that the relationship between health and economic performance is a very complex and diverse field of research. It is important to examine the current situation and identify possible intervention points to mitigate negative processes and to develop positive directions. We agree with the opinion of Palócz et al. (2006) that "Today in Hungary it is a key task to enhance the competitiveness of the country, which can be achieved, inter alia by improving the health status of the population."

\section{Material and methods}

For the analysis of the correlation between Hungary's health and economic indicators we used IBM SPSS Statistics 20 and Stata 13 software packages. The database we compiled formed the basis of the study, which contained the county level data of Hungary on the demographic, healthcare and economic situation. We collected the data from the Regional Healthcare Database of the National Healthcare Service Center. We used the most recent data available, which vary by variable, so the database included both 2011 and 2014 data. Given that we did not conduct a time series analysis, this methodologically did not cause any problems. Our research goal was to examine whether there is a statistically significant relationship between the health and economic indicators at county level and whether the Hungarian counties can be clustered on the basis of these indicators. If there is a correlation, what strength and direction does it have, and whether the neighbouring counties are in the same clusters.

In addition to the descriptive statistics, the applied methods were the following: the Pearson correlation, the Kaiser-Mayer-0lkin (KMO) and Bartlett's test, the Centroid weight-centroid method. The further aim of our study was to investigate some of the factors affecting mortality, and to create a multivariate linear regression function, with the help of which we can estimate the level of mortality at $95 \%$ significance level. Since the relationship existed between the examined variables, we created such an estimation (regression) function that estimates the number of deaths per thousand inhabitants at the level of significance accepted in the field of social sciences, taking into consideration as independent variables the per capita GDP, unemployment rate, monthly net average earnings of employees and students in higher education. During the construction of the model we examined the effects of the following indicators using the time series data of 18 Hungarian counties between 2001 and 2012:

$\square$ deaths per 1,000 inhabitants - 'deaths',

$\square$ GDP per capita (1,000 Ft/capita) - 'GDP',

$\square$ unemployment rate (\%) - 'employment',

$\square$ monthly net earnings per employee (HUF) - 'earnings',

$\square$ number of students in higher education institutions - 'students'.

Budapest and the Pest County were excluded from the analysis, with regard to the outlier values observed for several indicators compared to other counties, which could distort the results of the study. We collected data from the Regional Health Database and the Hungarian Central Statistical Office. In the framework of our research we tested the three hypotheses:

$\mathrm{H} 1$ : The variables included in the study have a significant effect on mortality.

$\mathrm{H} 2$ : The average monthly net earnings of employees affect mostly mortality.

H3: The number of students in higher education does not significantly influence mortality.

\section{Results and discussion}

Based on the Pearson correlation, there is a strong negative correlation between mortality and economic development at 95\% significance level. If the amount of GDP per capita (1,000 Ft/cap.) and/or R \& D expenditure (Million Ft) increases in a given county, it results in the decrease in mortality rate (per 1,000 inhabitants), which leads to the improvement of the health status of the population. This (apparently) generally accepted relationship makes it necessary to carry out further, more complex examinations on this topic. It has also been proved that in counties where more resources are spent on $R \& D$, the quality of healthcare is statistically justifiably higher. Compared to the other counties, the average number of institutions providing outpatient specialized care is higher, as is the number of licensed active hospitals, the outpatient cases financed by OEP (National Health Insurance Fund Administration) per 100 inhabitant, the financing of inpatient specialist care and the number of working doctors.

Before analysing the cluster, we examined whether the variables could be sorted into the optimal number of independent explanatory factors, based on the KMO and the Bartlett's test, trying to reduce the number of indicators. Since the indicator values of the tests were below 0.5 , it was not possible to sort the preliminary indicators into factors. Thus, in case of the examined variables, the common information was relatively low. Because of the lack of factors, we have manually selected those indicators that led to the grouping 
of counties. The indicators were chosen based on the theoretical findings of Kollányi and Imecs (2007) and the calculations of Fogel (1994), Barro (1996) and Bloom, Canning and Sevilla (2001). Due to the distorting effects mentioned earlier, Budapest and the Pest County were repeatedly excluded from the analysis. The 13 indicators included in the research were as follows:

$\square$ women's average life expectancy at birth;

$\square$ average life expectancy of men at birth;

$\square$ average age of women;

$\square$ average age of men;

$\square$ the rate of live births per thousand inhabitants;

$\square$ the rate of deaths per thousand inhabitants

$\square$ OEP financed outpatient cases per 100 inhabitants;

$\square$ unemployment rate (\%);

$\square$ number of operating enterprises per 1,000 people;

$\square$ gross Domestic Product per capita $(1,000$ HUF/capita);

$\square$ gross Value Added per capita (1,000 HUF/ capita);

$\square$ value of investments per capita $(1,000 \mathrm{HUF} /$ (apita);

$\square$ amount of $R$ \& $D$ expenditures (million HUF). Using the Centroid weight-centred method, we ran the cluster analysis and found that - based on the obtained dendrograms - the formation of four clusters seemed to be reasonable. Clusters based on the health and economic situation include the following counties:

$\square$ (Cluster 0: Budapest, Pest).

$\square$ Cluster 1: Borsod-Abaúj-Zemplén, BácsKiskun, Baranya, Fejér, Veszprém.

$\square$ Cluster 2: Heves, Jász-Nagykun-Szolnok, Komárom-Esztergom, Vas, Somogy, Szabolcs-Szatmár-Bereg, Nógrád, Békés, Zala, Tolna.

$\square$ Cluster 3:Győr-Moson-Sopron, Csongrád.

$\square$ Cluster 4: Hajdú-Bihar.

Figure 1 depicts the individual clusters and counties in colours. Overall, the health and economic indicators of the Gyorr-Moson-Sopron County and the Csongrád County from Cluster 3 were the most favourable. The Hajdú-Bihar County, which represents a standalone cluster, also performs well with the indicators. With respect to the examined indicators, the counties in Cluster 1 fall in the middle field, while the lagging counties belong to Cluster 2 regarding health and economic situation. $0 n$ the basis of the performed cluster analysis it can be stated that the health status of the population is typically

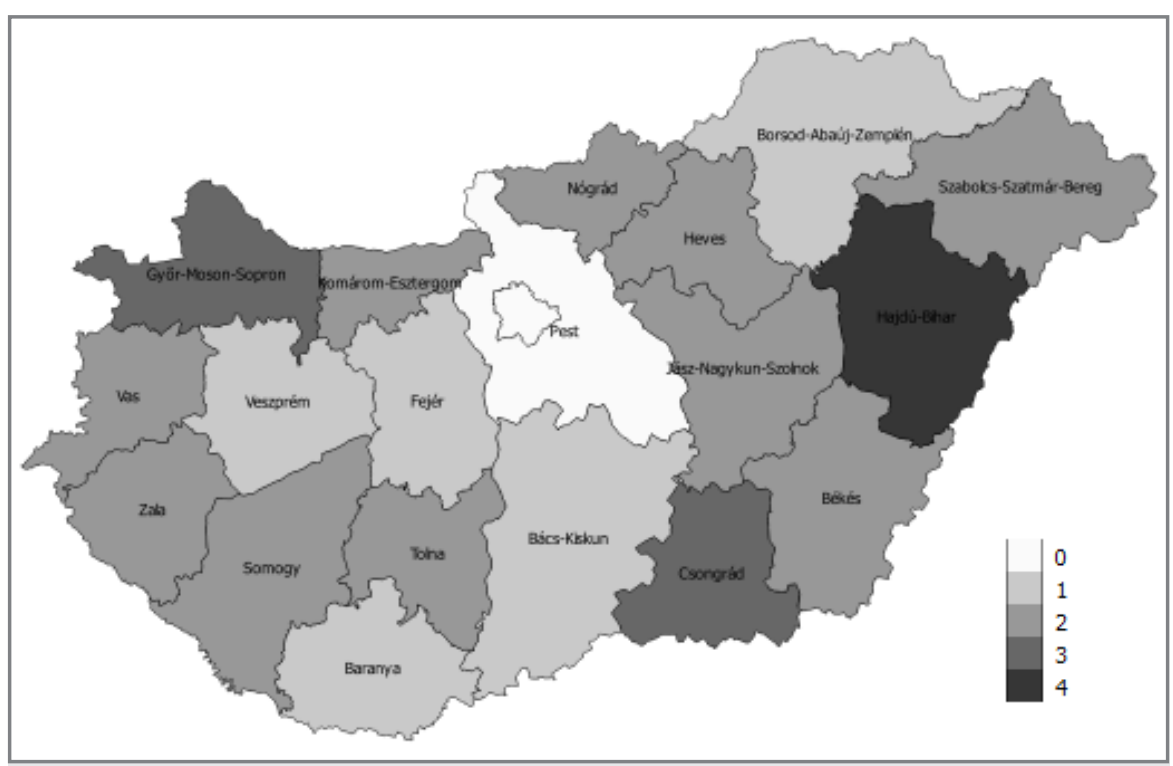

Figure 1 The counties of the clusters, by health and economic status Source: own editing, based on data from HCSO and the Regional Healthcare Database

heterogeneous at the county level, but it can be observed that neighbouring counties can be characterized by similar health and economic indicators.

The scattering of the counties in the clusters by the most important indicators and the relative position of the county groups are illustrated in boxplot diagrams. Based on the medians, average GDP per capita was the highest in the counties of Cluster 3 (3.442 million Ft/capita in Györ-Moson-Sopron, 2.146 million Ft/capita in (songrád). For counties belonging to (luster 1, the deviation of the indicator is the lowest, and the value of the Fejér County exceeds the group with the GDP of 2.657 million Ft per capita. The value of indicator called 'Number of outpatient cases financed by 0 EP per 100,000 inhabitants' was the second highest in the counties of Cluster 3 after Hajdú-Bihar, of which it can be concluded that the population is in poor health, but also that the specialized care services of these counties attract the residents of the surrounding counties, typically from Cluster 1 and 2 .

Before conducting the examinations, we assumed that mortality is related to GDP per capita, unemployment rate, monthly average net earnings of employees, and the number of students participating in the particular region's higher education. According to our hypothesis, average wages and the unemployment rate have a major impact on mortality at territorial level. We assumed a moderate correlation with GDP per capita, while we expected a poor correlation with the number of students, considering that someone who is currently studying in a particular settlement is not yet sure to settle, work and die there.

Prior to running the OLS estimation function, we examined the direction and intensity of the correlation between the investigated factors, based on the Pearson correlation coefficient.

According to the correlation analysis, the economic performance of a particular region measured in GDP is negatively correlated with the mortality rate, i.e. if economic situation improves, then mortality decreases. The increase in the unemployment rate entails an increase in mortality numbers. People who have lost their jobs are statistically more prone to illness, or, because of their inferior income position, healthcare is not necessarily provided, and likelihood of suicide increases statistically. If there is an increase in the number of higher education degrees in the region, the mortality rate shows a downward trend. Presumably because higher education students are much more enlightened and healthier than their counterparts, and students increase the GDP of a given area, which, as we have already explained above, has a beneficial effect on the decline in mortality. Not to mention that the income of people with higher qualification is typically higher, so that they are able to pay for a healthier lifestyle and prevention. The correlation between earnings and mortality is minimal, negligible.

Based on the results, the model of factors influencing mortality in Hungary can be written with the OLS estimation function as follows:

$$
\begin{aligned}
\text { mortality } & =c+\beta 1 \mathrm{GDP}+\beta 2 \text { unemployment }+\beta 3 \text { earnings }+\beta 4 \text { students } \\
y & =14.19-\beta 10.0016-\beta 20.05+\beta 30.000028-\beta 40.000031
\end{aligned}
$$


Table 1 OLS estimation

\begin{tabular}{|c|c|c|c|c|c|c|}
\hline \multirow[t]{2}{*}{ Source } & \multirow[t]{2}{*}{ SS } & \multirow[t]{2}{*}{ df } & \multirow[t]{2}{*}{ MS } & & Number of obs & $=216$ \\
\hline & & & & & $F(4,211)$ & $=28.58$ \\
\hline Model & 67.7839677 & 4 & 16.9459919 & & Prob $>F$ & $=0.0000$ \\
\hline \multirow[t]{2}{*}{ Residual } & 125.115616 & 211 & .592965003 & & $R$-squared & $=0.3514$ \\
\hline & \multirow[b]{2}{*}{192.899583} & \multirow[b]{2}{*}{215} & \multirow[b]{2}{*}{.897207364} & & Adj $R$-squared & $=0.3391$ \\
\hline Total & & & & & Root MSE & $=.77004$ \\
\hline Deaths & Coef. & Std. Err. & $t$ & $P>|t|$ & \multicolumn{2}{|c|}{ (95\% Conf. Interval) } \\
\hline Students & -0.0000311 & $5.53 \mathrm{e}-06$ & -5.62 & 0.000 & -0.000042 & -0.0000202 \\
\hline Unemployment & -0.0508872 & 0.0264468 & -1.92 & 0.056 & -0.103021 & 0.0012466 \\
\hline Earnings & 0.0000287 & $5.62 \mathrm{e}-06$ & 5.10 & 0.000 & 0.0000176 & 0.0000397 \\
\hline GDP & -0.0016189 & 0.0002382 & -6.80 & 0.000 & -0.0020884 & -0.0011495 \\
\hline _cons & 14.19376 & 0.2626572 & 54.04 & 0.000 & 13.67599 & 14.71153 \\
\hline
\end{tabular}

Source: own calculation based on data from $\mathrm{HCSO}$ and the Regional Healthcare Database

Mortality is affected by unemployment, GDP per capita, average monthly net income and the number of tertiary students in a county. The higher is GDP, the lower is the mortality rate in a given region. On the basis of regression, the number of deaths is influenced to a large extent by unemployment. In addition to all other unchanged factors, a unit increase in unemployment reduces mortality by 0.05 , which does not seem too probable. County data can affect this in an imaginable way. It would also be worthwhile to analyse these with national data. Furthermore, it would be worth examining the factors influencing mortality at county levels. The impact of student numbers and earnings is negligible in mortality (Table 1).

\section{Conclusions}

It has been proved that GDP per capita has the highest impact on mortality rates based on the correlation table. However, after the 0LS estimate, this was refuted, as a unit increase in unemployment by 0.05 reduces the mortality rate. We find this result relevant, therefore, we reject the hypothesis. It has also been proved that the variables included in the research have a significant effect on the mortality rate since $R$-squared $=0.3514$ which means a medium relationship.

The highest mortality rate was observed in the Nógrád County in 2011. The lowest was marked in the Fejér County in 2001 (11.4 persons/1,000 inhabitants), where the highest value in this period was 12.5 persons $/ 1,000$ inhabitants. This would suggest that GDP per capita in this county is the highest, but this is not true because in Györ-Moson-Sopron it was 3.456 million HUF in 2011, and such low mortality rates need to be explained by other factors not examined in our present study. Such a factor can be, for example, the quality of screening and of the healthcare system.

The main conclusion of our research is that studying the territorial inequalities of health status and its interactions with economic status is a complex and multifaceted task. The county level study area will have to be limited to a smaller territorial level, as a more in-depth analysis will be necessary (e.g. settlement or micro-regional level), in order to understand the cause-effect relationships. The results of modelling factors affecting mortality by the OLS estimation function were useful in testing our hypotheses and can become a proper starting point for further territorial research.

Our research results confirmed the fact that there is a statistically significant relationship between the economic and health situation of a particular region, and, in the light of the figures, significant territorial disparities can be observed in Hungary, encouraging the further expansion of the subject. Further research is justified in order to determine the possible points of intervention, mitigate negative processes (i.e. bad health status and economic burden of diseases) and define positive directions (models, action plans).

For the decision makers our suggestion is that a holistic approach is required for improving the population's health status in all regions. Instead of just focusing on the transfer of financial resources to healthcare system (which is obviously needed), the whole socio-economic situation has to be developed, due to the fact - as it was discovered in the literature review - that there is a positive feedback mechanism between economic performance and the health status: healthy people have better working ability, entrepreneurship, creativity, learning skills, and, through their enhanced economic performance, a more quality healthcare system can be maintained, which contributes to the better health situation of the population.

\section{References}

ÁCS, P. - HÉCZ, R. - PAÁR, D. - STOCKER M. 2011. A fittség (m)értéke. A fizikai inaktivitás nemzetgazdasági terhei Magyarországon. In Közgazdasági Szemle, vol. 58, July August 2011, p. 689-708.

ÁGOSTON, L. - IMECS, 0. - KOLLÁNYI, Z. - LISKA, J. - PULAI, A. 2007. Az életminőség fogalmán túl. Elméletek, módszerek és gondolatok az életminőség kapcsán. DEMOS Magyarország Alapítvány. Downloaded: 17.09.18. http://szekedi.ro/wp-content/ uploads/2012/02/DEMOSeletminoseg2007.pdf

BARÁTH, L. 2010. Az egészségügy közgazdasági és makrogazdasági összefüggései és erre alapozottan a Nemzeti Egészségügyi Stratégia szükségessége. Presentation. Magyar Közgazdasági Társaság 48. Bankok és közpénzügyek szekció, Szeged : Közgazdászvándorgyülés, 2010.

BARRO, R. J. 1996. Determinants of economic growth: a cross-country empirical study. NBER Working Paper 5698, Cambridge. http://www.nber.org/papers/w5698. pdf?new_window $=1$

BLOOM, D. E. - CANNING, D. - SEVILLA, J. 2001. The Effect of Health on Economic Growth: Theory and Evidence. NBER Working Papers 8587, 2001.

BOGNÁR, E. 2011. Egészséges társadalom - helyzetkép a magyar népesség egészségi állapotáról. Sopron : Empirica Gazdasági és Társadalomkutató Intézet Kft., 2011, 12 p.

EURÓPAI BIZOTTSÁG. 2009. Szolidaritás az egészségügyben: Az egészség terén mutatkozó egyenlőtlenségek csökkentése az Európai Unióban. Downloaded: 17.10.05. http:// ec.europa.eu/health/ph_determinants/socio_economics/documents/com2009_ hu.pdf 
EURÓPAI BIZOTTSÁG. 2013. Területi kohézió. Downloaded: 17.10.05. http://ec.europa.eu/ regional_policy/what/cohesion/index_hu.cfm

EURÓPAI KÖZÖSSÉGEK BIZOTTSÁGA. 2009. Egyenlötlenségek csökkentése az Európai Unióban. Downloaded: 17.10.05. http://ec.europa.eu/health/ph_determinants/ socio_economics/documents/com2009_hu.pdf

EUROPEAN COMMISSION. 2005. Health and Consumer Protection Directorate-General: The contribution of the health to the economy in the European Union. European Communities, 2005.

EUROPEAN COMMISSION. 2009. Commission Communication Solidarity in health: Reducing health in equalities in the EU. 2009.

FOGEL, R. W. 1994. Economic growth, population theory, and physiology: the bearing of long term processes on the making of economic policy. NBER Working Papers 4638, 1994.

GIDAI, E. 1998. A piac szerepe az egészségügyben - nemzetközi összehasonlítás. Egészségügy és piacgazdaság. Budapest : Magyar Tudományos Akadémia, 1998, pp. $5-26$.

GYEMSZI (REA) database. Downloaded: 17.10.09. http://imea.gyemszi.hu/Report/ ReportIndex.jsp?report=REA

KÁPOSZTA, J. 2014. Területi különbségek kialakulásának főbb összefüggései. In Gazdálkodás, 2014, no. 5, pp. 399-412.

KOLLÁNYI, Zs. - IMECS, 0. 2007. Az egészség - befektetés. Az egészségi állapot hatása a gazdasági teljesitőképességre és az életminőségre. Budapest: Demos Magyarország Alapítvány, 2007, 118 p. ISBN 978-963-8764-9-3-5.

KSH. 2010. Társadalmi helyzetkép. 2010.

KSH. 2011. Megyeszékhelyek a magyar-román határ két oldalán. 2011. ISBN 978963235 3340.

KSH. 2013. A fenntartható fejlődés indikátorai Magyarországon 2012. ISSN 2064-0307.

MALMBERG, B. - ANDERSSON, E. 2006. Health as a factor in regional economic development. Arbetsrapport, Institutet för Framtidsstudier - Institute for Futures Studies, 2006, no. 4. Downloaded: 17.10.09. file:///C:/Users/Dell/Downloads/20060 428104817fil7vf0kHdEx63nIUDTD3MG.pdf
OROSZ, É. 2001. Félúton vagy tévúton? Egészségügyünk félmúltja és az egészségpolitika alternatívái. Budapest : Egészséges Magyarországért Egyesület, 2001, 327 p.

PALÓCZ, É. - SZÖRFI, B. - BACHNÉ, H. M. - KOPINT, D. 2006. Az egészségügy és a versenyképesség kapcsolata. In IME V. évf. 3. szám, április, 2006, 14-17 pp.

PORTER, M. E. 2003. The economic performance of regions. In Reg. Studies, 2003, no. 37, pp. 549-578.

RAGÁNY, K. 2014. Az egészségügyi rendszerek jellemzői. Az egészségügy finanszírozása. Előadás. Semmelweis Egyetem, Egészségügyi Menedzserképző Központ. Downloaded: 17.10.09. http://semmelweis.hu/emk/files/2009/03/e\%C3\%BC_ rendszfinansz_rez_20140113_ragany_uj.pdf

REGIONÁLIS EGÉSZSÉGÜGYI ADATTÁR ON-LINE (REA). Downloaded: 17.10.09. http://imea. gyemszi.hu/Report/ReportIndex.jsp?report=REA

UZZOLI, A. 2009. A területiség szerepe az egészségügyi egyenlőtlenségek kialakulásában Magyarországon. Zárójelentés. PF63859 nyilvántartási számú 0TKA Egyéni Kutatási Posztdoktori Pályázat (2006-2009), Budapest, 2009, 93 p.

VARGA, J. 2014. A versenyképesség többszintǔ értelmezése és az innovációval való összefüggései. Doktori (Ph.D) Értekezés : Gödöllő : Szent István Egyetem, 2014, 215 p. WH0. 2001. National Mental Health Policy 2001-2005. 2001.

WIKIPÉDIA. Területi egyenlőtlenségek. Nemes Nagy J. (ed.) 2005. Regionális elemzési módszerek. ELTE Regionális Földrajzi Tanszék. Downloaded: 17.10.09. http:// hu.wikipedia.org/wiki/Ter\%C3\%BCleti_egyen|\%C5\%91tlens\%C3\%A9gek

\section{Contact address}

Izabella Mária Bakos, Szent István University, HU-2100 Gödöllö, Páter Károly u. 1. Hungary, e-mail: bakosizabella89@gmail.com 